\title{
The Influence of Work-Family Conflict and Perceived Organizational Support on Turnover Intention through Mediation Emotional Exhaustion on Indonesian Garment Workers
}

\author{
Monica Natalin ${ }^{1}$, Aryana Satrya ${ }^{2}$ \\ \{monicanatalin@gmail.com¹, aryana@ui.ac.id² ${ }^{2}$, \\ University of Indonesia, Jakarta ${ }^{12}$
}

\begin{abstract}
This study aimed to find the impact of emotional exhaustion (EE) mediation between work-family conflict (WFC), perceived organizational support (POS), and turnover intention (TI) in Indonesia garment industry's worker. This study is a part of the research conducted by the University of Indonesia (UI) research team, Tufts University (TU), Better Work-ILO (BW) and Real-Time Analytics (RTA) Vietnam. Data were collected based on survey questionnaires that obtained from surveys which was carried out by the core research team. The survey involved 2071 garment workers around DKI Jakarta, Banten, West Java, and Central Java Provinces. Hypotheses were tested with Structural Equation Model (SEM) method. The main result of this study showed that EE did not mediate the linkage between both WFC and TI, also the linkage between both POS and TI. Therefore, EE played an important role as a mediating variable in affecting the WFC and POS on TI.
\end{abstract}

Keywords: Emotional Exhaustion, Garment Workers, Perceived Organizational Support, Turnover Intention, Work-Family Conflict.

\section{Introduction}

In 2015-2019 the type of apparel industry is a priority to be built. Some criteria that determine the industry included in the priority category are having the potential of a rapidly growing market in the country, increasing the quantity and quality of employment, the potential to be able to compete in global markets, and having the potential to grow rapidly in independence [1]. In the last decade, apparel has also developed into a commodity from the creative industries commodity group. Clothing is included in the category Artisanal Products and Visual Arts [2]. The role of the textile and garment industry cannot be simply ignored because this industry contributes considerably not only to economic growth in Indonesia each year, but also in terms of providing employment and foreign exchange. The existence of the apparel industry in the regions of DKI Jakarta, Banten, West Java and Central Java will be a barometer 
for the apparel industry in other regions. Therefore, demographic bonuses and market opportunities, as well as access flexibility possessed by this region must be utilized as well as possible.

Better Work [3] revealed that 92.2 percent of the workforce in the Indonesian garment industry is a female workforce. As many as 80 percent of women who work in the garment sector are young or are considered to be of reproductive age (marriage and having children). Experts predict that the number of female workforce participation will continue to increase until 2019 along with greater access to education and training, as well as government efforts to support women's access to participate in existing employment opportunities [3].

Women have a difficult time balancing the fulfillment of family and work interests [4]. Individuals with high levels of psychological involvement in their work roles may be busier with their work and make them able to devote excessive amounts of energy to their work roles at the expense of their family roles, so they experience work-family conflicts [5], [6]. Therefore, work-family conflict becomes a gap for workers, especially women because they can not balance their family and work roles.

Yavas, Babakus, and Karatepe [7] found that work-family conflict can made unfriendly behavior due to emotional fatigue among hotel frontliner employees in Turkey. The symptoms of emotional exhaustion are that individuals feel tired and have no energy, loss of energy, frustration, loss of spirit and unable to provide good service [8]. Maertz and Campion [9] say that when employees experience emotional exhaustion, they lose their energy and feel that their emotional resources are dropped. Then, employees have the intention to quit because of the discomfort felt at work due to climax levels of emotional exhaustion.

There are several effects produced by emotional exhaustion and one of them is the increased intention to get out [10]. The reason is because the expected emotional expectations of the company provide a psychological effect that has the potential for someone to achieve emotional exhaustion and leave work [11]. Turnover intention is one of the negative results of emotional labor through surface acting dimensions that has an indirect effect on turnover through emotional exhaustion [12].

The relationship between perceived organizational support and emotional exhaustion was impacted work-family conflict [13]. Work-family conflict can be reduced if the organization provides support in the form of a fair reciprocal relationship from the organization so as to create trust from employees [34]. This is supported by research by Casper, Martin, Buffardi, and Erdwins [14] who found that the high perceived organizational support makes the level of 
work-family conflict lower because organizations provide support so that they can maintain demands in work and households well.

Employees who have high perceived organizational support can reduce work-family conflicts that are happening because they feel supported and become coping and reduce work stress experienced [15]. Karatepe [16] shows that frontline employees who get enough support from the organization have a great level of effectiveness, are intrinsically motivated so that they experience a low level of emotional fatigue and a desire to move.

By considering emotional exhaustion as a mediating variable work-family conflict and perceived organizational support relationship with turnover intention, there are two contributions given by this study. The first contribution is to answer the problem formulation, know the research gaps, and provide conclusions and suggestions for work-family conflict, perceived organization support, and emotional exhaustion on turnover intention context among Indonesian garment workers. Then, hopefully can encourage future research which are interested in policy making for management and related stakeholders, so work in the workplace, welfare and quality of workforce in the Indonesian garment industry can be better and turnover rates for garment workers in Indonesia can be reduced.

\section{Hypotheses Development}

\subsection{Work-Family Conflict}

Basically people have limited capacity so individuals will have limitations in carrying out their roles both in the office or at home. If someone receives a lot of pressure at work, their role at home will be disrupted. When this happens, one's life satisfaction will decrease and emotional exhaustion will increase. Work-family conflict has a significant positive effect on emotional exhaustion [17]. It proves that the high work-family conflict of lecturers also encourages the emotional fatigue experienced. Conversely, work-family conflict experienced by lecturers is low, so emotional fatigue experienced by lecturers will decrease. Prajogo [18] also examines work-family conflict in emotional exhaustion. The effect of work-family conflict on positive emotional exhaustion, means that the higher the individual experiences of family work conflict, the more vulnerable the individual experiences emotional exhaustion. Thus, workers no longer enjoy the work they do.

Research Batt and Valcour [19] prove that work-family conflict is positively and significantly connected to the desire to move, so that various work-family policies or programs can be determined in advance to be effective and appropriate to reduce turnover intention. Haar [20] also concluded that 
work-family conflict has a positive effect on the occurrence of turnover intention in government workers in New Zealand.

Research by Blomme, Rheede, Tromp, Absar, and Mahmood [21] also Ghayyur and Waseef [22] also suggest that work-family conflict has a significant positive effect on turnover intention. Alsam, Sadaf, Mahwish, and Shama [23] also found that work-family conflict had a significant positive effect on turnover intention. Erkmen and Esen [24] also prove that work-family conflict influences turnover intention with responsibility towards family as the main predictor of turnover intention.

Eisenberger, Armeli, Rexwinkel, Lynch, and Rhoades [34] who explain that work-family conflict can be reduced if the organization provides support in the form of a fair reciprocal relationship from the organization so as to create trust from employees. In addition, this study is also different from Casper, Martin, Buffardi, and Erdwins [14] who revealed that the high perceived organizational support makes the level of work-family conflict lower. Foley, Hang-yue, and Lui [35] who concluded that perceived organizational support is negatively related to work-family conflict, if when perceived organizational support is high, perceived organizational support can reduce work-family conflict.

H1. Work-family conflict is positively related to emotional exhaustion.

$\mathrm{H} 2$. Work-family conflict is positively related to turnover intention.

H3. Work-family conflict is negatively related to perceived organizational support.

\subsection{Perceived Organizational Support}

Research conducted by Kraemer and Gouthier [25] proves that perceived organizational support (dimensions of job pressure, work interruptions, job routinization) has a negative effect on emotional exhaustion. Eisenberger, Stinglhamber, Vandenberghe, Sucharski, and Rhoades [34] also explain that perceived organizational support has a significant negative effect on turnover intention. Then, Allen, Shore, and Griffeth [27] have also empirically proven that perceived organizational support is significantly negatively related to turnover intention through the mediating influence of commitment and high job satisfaction, thus giving a low employee tendency towards turnover intention [28].

H4. Perceived organizational support is negatively related to emotional exhaustion.

H5. Perceived organizational support is negatively related to turnover intention. 


\subsection{Emotional Exhaustion}

Knudsen, Ducharme, and Roman [29] managed to prove that the emotional fatigue variable had a significant positive effect on intention to leave. The same finding was also stated by Churiyah [30] that emotional exhaustion had a positive effect on turnover intensity. The results of Kraemer and Gouthier's research [25] conducted on 252 call center agents also said that emotional exhaustion had a positive effect on turnover intention.

Faisal [31] also examined the effect of emotional exhaustion as a mediator in 213 National Banking employees in the city of Banda Aceh (Branch Offices of Bank Rakyat Indonesia, Bank Nasional Indonesia, and Bank Mandiri), namely emotional exhaustion mediating the effect of work overload on job embeddedness, and mediate the effect of work-family conflict on job embeddedness. Research using emotional exhaustion as a mediator was also conducted by Poernomo and Wulansari [17] who stated that emotional exhaustion also mediates between work-family conflict and performance. Septyaningsih and Palupiningdyah [32] also explained that when nurses experience work-family conflict, it can increase emotional exhaustion in nurses but ultimately can reduce nurse performance. In other words, emotional exhaustion mediates between work-family conflict and performance. Other research that uses emotional exhaustion (the dimension of burnout) as a mediator was also conducted by Handoko and Yuniawan [33] on married employees of the Semarang City Population and Civil Registry Office. Based on these descriptions, researchers want to see how does emotional exhaustion mediates the work-family conflict relationship with turnover intention, and perceived organizational support with turnover intention.

H6. Emotional exhaustion is positively related to turnover intention.

H7. Emotional exhaustion will mediate the relationship between work-family conflict and turnover intention.

H8. Emotional exhaustion will mediate the relationship between perceived organizational support and turnover intention.

\section{Method}

\subsection{Study Procedure}

This study is a part of the research conducted by the University of Indonesia (UI) research team, Tufts University (TU), Better Work-ILO (BW) and Real-Time Analytics (RTA) Vietnam. Data were collected based on survey 
questionnaires that obtained from surveys which was carried out by the core research team. Prior to filling out the questionnaire, respondents had ascertained that the data obtained would only be used for research purposes.

\subsection{Participant}

Based on the details of secondary data (table 1), the number of research samples were 86 companies and only 2,071 of 3540 respondents were valid after cleaning the data. Based on demographic characteristics (table 2), women workers more dominant than men $(82.9 \%)$; workers are still dominated by generation $\mathrm{Y}$ from aged 20 to 30 years $(42.5 \%)$; elementary school education is more dominant in line with the work system of contract / labor status (outsourcing); and majorities were married (69.7\%).

\subsection{Measurement}

Referring to the secondary data that the researcher received, this study includes quantitative research with data processing using the Statistical Program for Social Studies (SPSS) version 22 software for measuring instruments. Then, two items with a rating scale of 1 to $7(1=$ never; $2=$ several times in comparison; 3 = monthly; 4 = several times in accordance; 5 = every week ; 6 $=$ several times a week; 7 = every day) as the basic measurement of emotional exhaustion. After that, 5 point likert scale ranging from 1 (strongly disagree) to 5 (strongly agree) to measure perceived organizational support, work-family conflict, and turnover intention. There're also two dimensions namely working conditions and empowerment that used regarding perceived organizational support and the Structural Equatation Model (SEM) method with Lisrel 8.7 software to test hypotheses of this study.

\section{$4 \quad$ Results}

Based on table 3, the level of work-family conflict possessed by workers is at a medium level. From the same table it can also be seen that workers feel that the perceived organization support that they have is at a high level. The results also showed that the average emotional exhaustion was in the low category. That is, the level of fatigue due to work demands felt by workers on average is low. While for the turnover intention variable, the average value is included in the low category. So that it can be interpreted that the average worker has a low willingness to get out from the job and choose to continue working in the garment industry.

Meanwhile, the values of other compatibility tests such as GFI (0.97), RMSEA (0.06), SRMR (0.036), and CFI (0.98) indicated a good fit to the 
observed data. From discriminant validity statistic (table 4), it could be seen that the $\mathrm{CR}$ values of all variables in the measuring instrument have met these requirement. Meanwhile the measuring instrument was also said to be reliable if the value of the variance extracted measure (VE) was more than or equal to 0.5 . Another result also showed that only perceived organizational support variable did not meet these requirements. However, it still could be concluded that the instrument used to measure the turnover intention in this research were reliable.

From table 5, hypothesis 3 which tests the hypothesis that work-family conflict has a significant negative relationship to perceived organization support shows a statistically significant value and the direction of the relationship that is in line with expectations $(\mathrm{p}=-14.55, \beta=-0.17)$ so that hypothesis 3 be accepted. Hypothesis 4 tests that the perceived organization support has a significant negative effect on emotional exhaustion which has a statistically significant value $(p=-9.39, \beta=-0.26)$ and the direction of the relationship as expected so that hypothesis 4 is also accepted. Hypothesis 5 which tests that there is a negative relationship between perceived organization support and turnover intention also shows a statistically significant number $(\mathrm{p}=-7.36, \beta=-$ 0.23 ) and has the direction of the relationship as expected so that it can be said that hypothesis 5 is accepted.

While hypothesis 1 which predicts the relationship between work-family conflict and emotional exhaustion failed to be accepted. This is due to not achieving the value of acceptance of the hypothesis $(p=0.16, \beta=0.27)$ even though the direction of the relationship is as expected. Rejection also occurs in hypothesis 2 which tests work-family conflict relationships with turnover intention. The significance value of the relationship failed to reach the acceptance value of the hypothesis $(p=-5.32, \beta=-0.01)$ even though the direction of the relationship was in the expected direction. Hypothesis 6 which tests that there is a positive relationship between emotional exhaustion and turnover intention also be rejected because statistically significant number shows $\mathrm{p}=0.9$ and $\beta=0.47$.

Hypotheses 7 and 8 examine the role of emotional exhaustion as a mediating variable between work-family conflict (hypothesis 7 ) and perceived organizational support (hypothesis 8) with turnover intention. The hypothesis of this study states that emotional exhaustion is able to mediate the effect of workfamily conflict on turnover intention. Hair, Black, Babin, and Anderson [36] state that when viewed from a comparison of the significance of the influence possessed by the relationship of each variable, both directly and indirectly, emotional exhaustion is not able to mediate both the effect of work-family conflict on turnover intention and the effect of perceived organizational support 
on turnover intention.

The effect of work-family conflict on turnover intention if not through emotional exhaustion is significant also proves in Figure 2. If through emotional exhaustion, the effect of work-family conflict on emotional exhaustion and emotional exhaustion on turnover intention is not significant. In Figure 3, it can be seen also that the effect of perceived organizational support on emotional exhaustion is significant, but the effect of emotional exhaustion on turnover intention is not significant. If not through emotional exhaustion, perceived organizational support's influence on turnover intention (direct effect) is significant.

When referring to the Sobel test by comparing the z-count value and ztable value with a significance level of 0.05 , it is known that both $\mathrm{H} 7$ and $\mathrm{H} 8$ hypothesis are accepted because it has a z-count value greater than the Z-table value [37]. The Sobel test concluded that emotional exhaustion mediates both work-family conflict against turnover intention, and perceived organizational support against turnover intention. The mediation of emotional exhaustion on the effect of work-family conflict on turnover intention and perceived organizational support on turnover intention is described in the following table 6.

Proof of mediation based on the theories of Hair, Black, Babin, and Anderson [36] and Sobel [37] shows the existence of a gap (difference) results. These findings encourage researchers to be more careful in making mediation conclusions. On the basis of this caution, researchers chose to decide to follow the theory of Hair, Black, Babin, and Anderson [36] that emotional exhaustion does not mediate the effect of work-family conflict on turnover intention, and perceived organizational support on turnover intention.

\section{Discussion}

The result showed that the large number of female workers dominated the garment industry and there was an increase in the number of female labor force participation. Some of the female workers are married and have children so the concentration is divided into work and household. When female workers cannot meet family and company responsibilities (demands) in a balanced manner, and have a good quality of life, then workers will experience WFC.

In the variable WFC, the item questionnaire that has the highest loading is "what I want to do at home cannot be done because of work demands". In the variable POS, the dimension that has the highest loading is the dimension of working conditions with the questionnaire "I face injustice in assignment of 
work". In the EE variable, the item with the highest loading questionnaire was "I feel tired when I wake up in the morning and have to face another day at work". In the TI variable, the item of the questionnaire that has the highest loading is "thinking of moving to a job in a sector other than the textile and apparel sector".

From Figure 4, it can be concluded that POS mediates the relationship between WFC and TI. So, if workers feel that they cannot do other things at home because the workload also feels unfairness in their work assignment, then workers will want to move to the non-textile and garment sector. If there is a conflict between work and family, workers will have a desire to quit their job if they feel they do not receive organizational support.

\section{Managerial Implication}

Work-family conflicts experienced by garment workers occur because garment workers do not have a good quality of life due to the work provided by the company which takes up too much time for workers so workers find it difficult to fulfill their social and family responsibilities. Job demands provided by companies prevent workers from enjoying their social and family lives. The number of jobs in the company makes garment workers unable to fulfill his responsibilities in the family. Workers actually experience frustration with their work and are tired in carrying out their days at work.

Working conditions in garment companies do not make workers feel comfortable. Long working hours, excessive workload (not in accordance with the capacity of workers), high work demands, internal conflicts, and lack of support from supervisors (supervisors) make garment workers unable to carry out their responsibilities in the family. These working conditions make workers feel sleepy, lethargic, unenthusiastic, and unenthusiastic in completing their work. Emotional fatigue experienced by workers ultimately reduces the quality of life and quality of workers.

The dimensions of work conditions and empowerment provide the biggest contribution in building positive perceptions of workers regarding job characteristics in the garment industry. Working conditions are the most important dimension in preventing workers' intention to leave, while empowerment is an important dimension in increasing the work ethic of workers when experiencing work-family conflict, and increasing the skills and creativity of workers. However, guarantees for occupational health and safety (K3), psychological factors, work systems and treatment from management (low labor costs, high work pressure and deadlines, irregular working hours, rare 
communication from superiors), and attention (support) the organization of the welfare of garment workers is still low. The management of the garment industry must pay more attention also for human resource management practices related to work systems and programs that are fair, flexible, and relevant to the emotional exhaustion worker problem.

\section{Limitation}

Secondary data that researcher received and processed from the core research team were only the form of questionnaires that had been filled out by respondents. So that, researcher could not conduct in-depth interviews with respondents to confirm the results. Another limitation is related to the sample that used in this study. This study also did not involve variations in the minimum wage (UMP) by province or district minimum wage (MSE) as a differentiator and specific comparison between the garment industry from one another. In future studies, researchers suggest adding financial factors as well as other relevant employment and industrial policies. The last limitation is this study did not conducted in a specific place such as a particular company, or in a particular industry so it cannot be ascertained that the results of this study will always be the same if examined in different places, times, and respondents. It is possible if future studies are conducted using different respondents, samples, variables, locations, and times so that different results will be obtained from research conducted by researchers at this time.

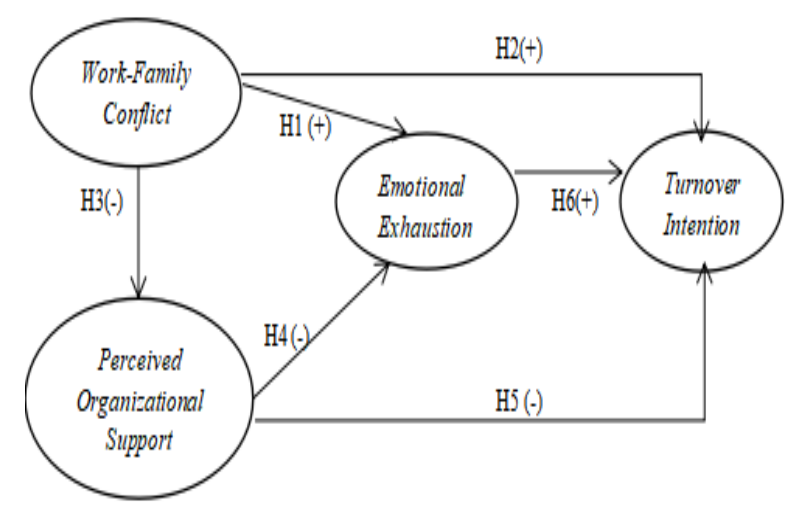

Figure 1. Proposed path model. Modified from [16]; [25]; [38]; [39]

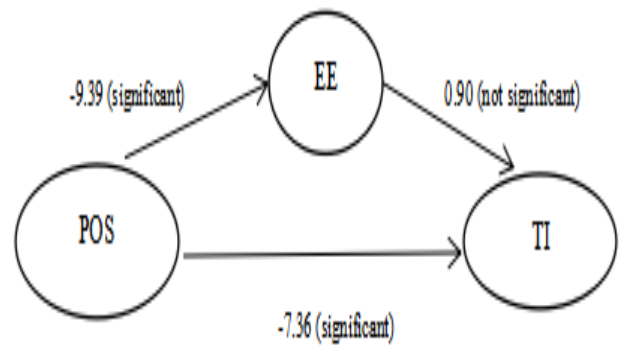




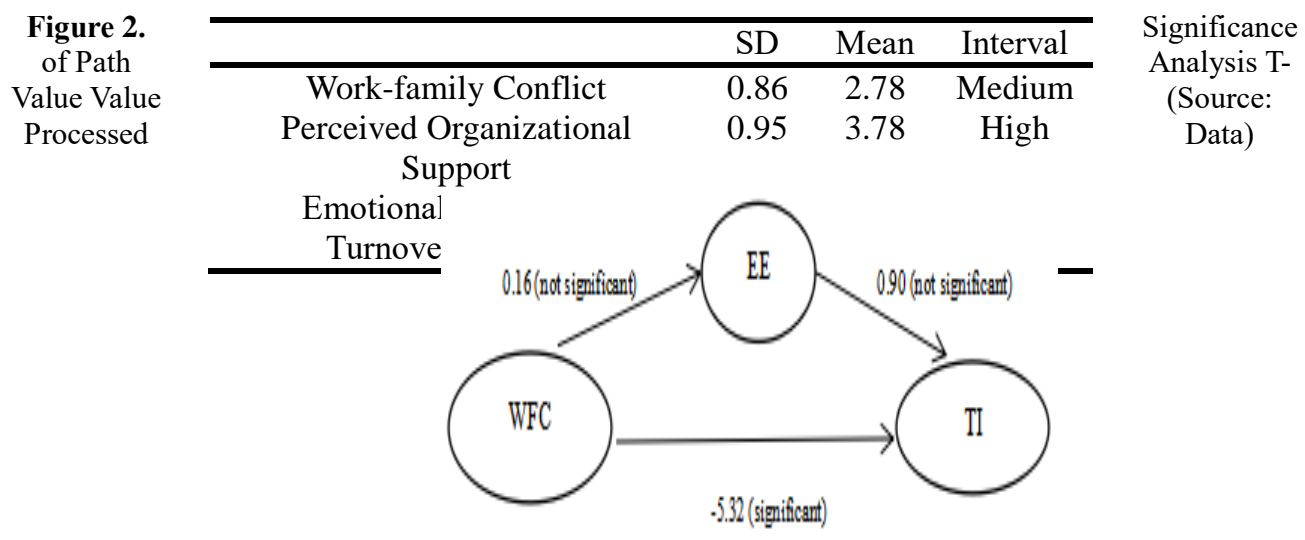

Figure 3. Significance of Path Analysis T-Value Value (Source: Processed Data)

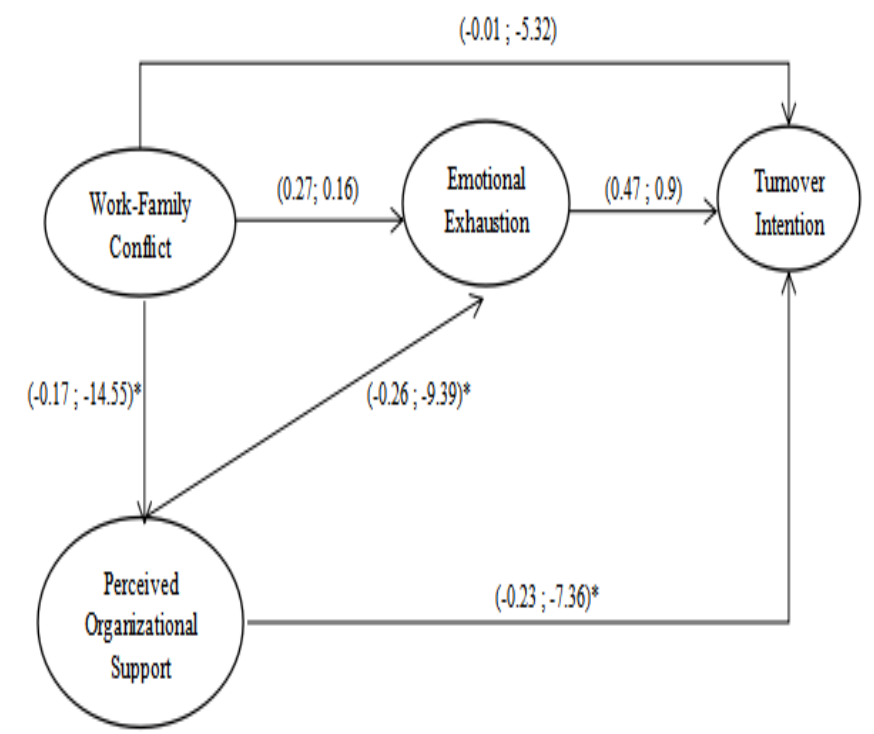

Figure 4. Significance of Path Analysis T-Value and Coefisien Value $(\beta \geq 0.05 ; p \geq 1.96)$ Source: Processed Data

Table 1. Details of Secondary Data

Source: Output SSPS vers.22 
Table 2. Demographic Characteristic

\begin{tabular}{|c|c|c|c|c|c|}
\hline Province & City & Companies & $\Sigma$ Companies & Respondents & $\Sigma$ Total Respondents \\
\hline DKI Jakarta & Jakarta & 6 & 6 & 260 & 260 \\
\hline \multirow[t]{5}{*}{ Banten } & Tangerang & 4 & 4 & 200 & 200 \\
\hline & Bekasi & 2 & 46 & 70 & 2010 \\
\hline & Karawang & 4 & & 170 & \\
\hline & Bogor & 10 & & 440 & \\
\hline & Sukabumi & 8 & & 340 & \\
\hline \multirow[t]{4}{*}{ West Java } & Cianjur & 2 & & 100 & \\
\hline & Bandung & 10 & & 410 & \\
\hline & Purwakarta & 2 & & 80 & \\
\hline & Subang & 8 & & 400 & \\
\hline \multirow[t]{2}{*}{ Central Java } & Semarang & 18 & 26 & 640 & 930 \\
\hline & Solo & 2 & & 80 & \\
\hline \multirow[t]{4}{*}{ Yogyakarta } & Klaten & 2 & & 80 & \\
\hline & Boyolali & 4 & & 130 & \\
\hline & Yogyakarta & 4 & 4 & 140 & 140 \\
\hline & Total & & 86 & & 3540 \\
\hline
\end{tabular}


Table 3. Variable Validity Statistic

\begin{tabular}{cccccccc}
\hline Pattern & a & b & SEa & SEb & Z & Ztabel & Conclusion \\
\hline WFC_EE_TI & 0,27 & 0,47 & 0,031 & 0,069 & 5,3658 & 1,96 & H7 accepted \\
POS_EE_TI & 0,26 & 0,47 & 0,067 & 0,069 & 3,3757 & 1,96 & H8 accepted \\
\hline
\end{tabular}

Source: Output SSPS vers.22

Table 4. Descriptive Statistic

\begin{tabular}{lcc}
\hline & CR & VE \\
\hline Work-family Conflict & .88 & 0.79 \\
Perceived Organization Support & .55 & .45 \\
Emotional Exhaustion & .66 & .50 \\
Turnover Intention & .87 & .50 \\
\hline
\end{tabular}

Source: University of Indonesia Research Team Secondary Data (2018)

Table 5. Hypotheses Testing

\begin{tabular}{lccc}
\hline & $\mathrm{p}$ & $\beta$ & Remarks \\
\hline WFC $\rightarrow$ EE & 0,16 & 0,27 & Hypothesis 1 rejected \\
WFC $\rightarrow$ TI & $-5,32$ & $-0,01$ & Hypothesis 2 rejected \\
WFC $\rightarrow$ POS & $-14,55$ & $-0,17$ & Hypothesis 3 accepted \\
POS $\rightarrow$ EE & $-9,39$ & $-0,26$ & Hypothesis 4 accepted \\
POS $\rightarrow$ TI & $-7,36$ & $-0,23$ & Hypothesis 5 accepted \\
EE $\rightarrow$ TI & 0,9 & 0,47 & Hypothesis 6 rejected \\
\hline
\end{tabular}

Source: Output SSPS vers.22 
Table 6. Hypotheses Testing Z Value Calculated Sobel Test

\begin{tabular}{lc}
\hline & \% of respondents \\
\hline Gender & \\
Women & 82.9 \\
Men & 17.1 \\
Age groups & \\
$<20$ & 8.5 \\
$20-30$ & 42.5 \\
$31-40$ & 37.1 \\
$41-50$ & 11.1 \\
$>$ 50 & 0.9 \\
Education & \\
Elementary school & 40.7 \\
Middle school & 18.0 \\
High school & 6.3 \\
Technical education & 33.5 \\
Diploma / graduate & 1.5 \\
Marrital status & \\
Single & 29.0 \\
Married & 69.7 \\
\hline
\end{tabular}

Source: Output SSPS vers.22

\section{References}

[1] Kementerian Perindustrian. 2014. Rencana induk pembangunan industri nasional 2015-2035. Jakarta: Kementerian Perindustrian.

[2] International Trade Center. 2015. Creative industries. Diakses Mei 21, 2018 dari http://www.intracen.org/itc/sectors/creative-industries/.

[3] ILO. 2014. Wages and working hours in the textiles, clothing, leather and footwear industries (1st ed.). Geneva: International Labour Organization. Retrieved from= http://ilo.org/wcmsp5/groups/public/-ed_dialogue/---sector/documents/meetingdocument/wcms_345739.pdf.

[4] Posig, M.and Kickul, J. 2004. Work-role expectations and work family conflict: gender differences in emotional exhaustion. Women in Management Review, 19(7): 373-386. DOI= https://doi.org/10.1108/09649420410563430.

[5] Hammer, L. B., Allen, E., and Grigsby, T. D. 1997. Work and family conflict in dual-earner couples: Within-individual and crossover effects of work and family. Journal of Vocational Behavior, 50(2): 185203. DOI= https://doi.org/10.1006/jvbe.1996.1557.

[6] Darcy, C.and Carthy, A. M. 2007. Work-family conflict: An exploration of the differential effects of a dependent child's age on working parents. Journal of European Industrial Training, 31(7): 530-549. DOI= https://doi.org/10.1108/03090590710820042.

[7] Yavas, U., Babakus, E., and Karatepe, O. 2008. Attitudinal and behavioral consequences of work-family conflict and family-work conflict. does gender matter?. International Journal Service Industry 
Management, 19(1): 7-31. DOI=https://doi.org/10.1108/09564230810855699.

[8] Christianto, G.dan Putra, M. S. 2016. Pengaruh emotional exhaustion dan motivasi kerja terhadap kepuasan kerja karyawan. E-Jurnal Manajemen Unud, 5(5): 2786-2813.

[9] Maertz, J. C.and Campion, M. 2004. Profiles in quitting: integrating process and content turnover theory. Academy of Management Journal, 47(4): 566-582. DOI= https://doi.org/10.5465/20159602.

[10] Moore, J. E. 2000. Why is this happening? A causal attribution approach to work exhaustion consequences. Academy of Management Review, 25(2): 335-349. DOI= https://doi.org/10.2307/259017.

[11] Grandey, A. A. 2000. Emotional regulation in the workplace: a new way to conceptualize emotional labor. Journal of Occupational Health Psychology, 5(1): 95-110. DOI= https://doi.org/10.1037/10768998.5.1.95.

[12] Chau, S. L., Dahling, J. J., Levy, P. E., and Diefendorff, J. M. 2009. A predictive study of emotional labor and turnover. Journal of Organizational Behavior, 30(8): 1151- 1163. DOI= https://doi.org/10.1002/job.617.

[13] Hamwi, G. A., Rutherford, B. N., and Boles, J. S. 2011. Reducing emotional exhaustion and increasing organizational support. Journal of Business dan Industrial Marketing, 26(1): 4-13. DOI=https://doi.org/10.1108/08858621111097166.

[14] Casper, W. J., Martin, J. A., Buffardi, L. C., and Erdwins, C. J. 2002. Work family conflict, perceived organizational support, and organizational commitment among employed mothers. Journal of Occupational Health Psychology, 7(2): 99-108. DOI= https://doi.org/10.1037/1076-8998.7.2.99.

[15] Somech, A.and Zahavy, A. D. 2012. Coping with work-family conflict: the reciprocal and additive contributions of personal coping and organizational family-friendly support. Work and Stress, 26(1): 6890. DOI= https://doi.org/10.1080/02678373.2012.660361.

[16] Karatepe, O. 2015. Do personal resources mediate the effect of perceived organizational support on emotional exhaustion and job outcomes?. International Journal of Contemporary Hospitality Management, 27(1): 4-26. DOI= https://doi.org/10.1108/IJCHM-09-2013-0417.

[17] Poernomo, U. D.dan Wulansari, N. A. 2015. Pengaruh konflik antara pekerjaan-keluarga pada kinerja karyawan dengan kelelahan emosional sebagai variabel pemediasi. Management Analysis Journal, 4(3): 190-199.

[18] Prajogo, W. 2016. Work family sinergy: anteseden dan konsekuen. JBTI, 1(1): 1-16. Retrieved from= https://journal.umy.ac.id/index.php/bti/article/view/2542/2515.

[19] Batt, R.and Valcour, P. M. 2003. Human resources practices as predictors of work-family outcomes and employee turnover. Industrial Relations, 42(2): 1-45. DOI= https://doi.org/10.1111/1468-232X.00287.

[20] Haar, J. 2004. Work-family conflict and turnover intention: exploring the moderation effects of perceived work-family support. New Zealand Journal of Psychology, 33(1): 35-39. Retrieved from = https://www.psychology.org.nz/journal-archive/NZJP-Vol331-2004-5-Haar.pdf.

[21] Blomme, R. J., Rheede, A. V., Tromp, D. M., Absar, M. M. N., and Mahmood, M. 2010. Work-family conflict as a cause for turnover intentions in the hospitality industry. Tourism and Hospitality Research, 10(4): 269 - 285. DOI= https://doi.org/10.1057/thr.2010.15.

[22] Ghayyur, M.and Waseef, J. 2012. Work-family conflflicts: a case of employees' turnover intention. International Journal of Social Science and Humanity, 2(3): 168-174. DOI= 10.7763/IJSSH.2012.V2.90.

[23] Alsam, N., Imran, R., Anwar, M., Hameed, Z., and Kafayat, A. 2013. The impact of work-family conflicts on turnover intention an empirical evidence from Pakistan. World Applied Science Journal, 24(5): 628-633. DOI= 10.5829/idosi.wasj.2013.24.05.13227

[24] Erkmen, T.and Esen, E. 2014. Work family, family work conflict and turnover intentions among the 
representatives of insurance agencies. Journal of Business, Economics, and Finance, 3(3): 302-312. DOI= https://dergipark.org.tr/tr/pub/jbef/issue/32410/360452.

[25] Kraemer, T.and Gouthier, M. H. J. 2014. How organizational pride and emotional exhaustion explain turnover intentions in call centers: a multi-group analysis with gender and organizational tenure. Journal of Service Management, 25(1): 125-148. DOI= https://doi.org/10.1108/JOSM-07-2013-0173.

[26] Eisenberger, R., Stinglhamber, F., Vandenberghe, C., Sucharski, I., and Rhoades, L. 2002. Perceived supervisor support: contributions to perceived organizational support and employee retention. Journal of Applied Psychology, 87(3): 565-573. DOI= https://doi.org/10.1037/0021-9010.87.3.565.

[27] Allen, D. G., Shore, L. M., and Griffeth, R. W. 2003. The role of perceived organizational support and supportive human resource practices in the turnover process. Journal of Management, 29(1): 99-118. DOI= https://doi.org/10.1177/014920630302900107.

[28] Kahumuza, J.and Schlechter, A. F. 2008. Examining the direct and some mediated relationships between perceived support and intention to quit. Management Dynamics, 17(3): 2-19. retrieved from = https://www.researchgate.net/publication/304784163_Examining_the_direct_and_some_mediated_rela tionships_between_perceived_support_and_intention_to_quit.

[29] Knudsen, H. K., Ducharme, L. J., and Roman, P. M. 2008. Clinical supervision, emotional exhaustion, and turnover intention: a study of substance abuse treatment counselors in the clinical trial network of the national institute on drug abuse. Journal of Substance Abuse Treatment, 35(4): 387-395. DOI= https://doi.org/10.1016/j.jsat.2008.02.00.

[30] Churiyah, M. 2011. Pengaruh konflik peran, kelelahan emosional terhadap kepuasan kerja dan komitmen organisasi. Jurnal Ekonomi Bisnis, 16(2): 145-154.

[31] Faisal, M. 2015. Pengaruh work overload, work-family conflict, dan familywork conflict terhadap job embeddedness karyawati perbankan nasional Banda Aceh dengan emotional exhaustion sebagai variabel mediasi. Skripsi, Fakultas Ekonomi Universitas Syiah Kuala Darussalam, Banda Aceh.

[32] Septyaningsih, R.dan Palupiningdyah. 2017. Pengaruh beban kerja berlebih dan konflik pekerjaan keluarga terhadap kinerja melalui kelelahan emosional. Management Analysis Journal, 6(4): 461-472.

[33] Handoko, P. A., dan Yuniawan, A. 2017. Pengaruh kualitas kepemimpinan, konflik pekerjaan keluarga, dan dukungan sosial terhadap presenteeism dengan burnout sebagai variabel interverning. Diponegoro Journal of Management, 6(4): 1-13. Retrieved from= http://ejournal-s1.undip.ac.id/index.php/dbr.

[34] Eisenberger, R., Armeli, S., Rexwinkel, B., Lynch, P. D., and Rhoades, L. 2001. Reciprocation of perceived organizational support. Journal of Applied Psychology, 86(1): 42-51. DOI= https://doi.org/10.1037/0021-9010.86.1.42.

[35] Foley, S., Hang, Y. N., and Lui, S. 2005. The effects of work stressors, perceived organizational support, and gender on work-family conflict in Hong Kong. Asia Pacific Journal of Management, 22(3): 237256. DOI= https://doi.org/10.1007/s10490-005-3568-3.

[36] Hair, J.F., Black, W.C., Babin, B.J., Anderson, R.E., and Tatham, R.L. 2010. Multivariate data analysis (6th ed.). Upper Saddle River, NJ: Pearson Prentice Hall.

[37] Sobel, M. E. 1982. Asymptotic confidence interval for indirect effects in structural equation models. In S. Leinhardt (Ed.). Sociological Methodology. Washington DC: American Sociological Association, 290-312.

[38] Aycan, Z., \& Eskin, M. (2005). Relative contributions of childcare, spousal support, and organizational support in reducing work-family conflict for men and women: The case of Turkey. Sex roles, 53(7-8), 453-471.

[39] Ghosh, P., Chauhan, R., \& Rai, A. (2015). Supervisor support in transfer of training: Looking back at past research. Industrial and Commercial Training. 